\title{
Pirandello and the Resistance to Tragedy David Groves
}

Could a man write the word "tragedy" across a blank page without hearing at his back the immense presence of the Oresteia, of Oedipus, of Hamlet, and of King Lear? ${ }^{1}$

How many writers have in fact written "tragedy" across a blank page since the Romantics, since the post-Napoleonic days of, say, the adolescent Hugo's Irtamène (1816), Shelley's The Cenci and Keats' Otho The Great (1819), Manzoni's Adelchi (1822)? Pirandello, though, was one who did. This essay explores the Freudian game of fort- $d a$, of throwing it away and wanting it back, that Pirandello played with tragedy, the word and the thing. It comments not only on Pirandello's principal "tragedy," Henry IV (Enrico IV), but more especially on marginalised themes of violence and sacrifice in Pirandello's most famous play Six Characters in Search of an Author (Sei personaggi in cerca d'autore).

\section{Tragedy}

Henry IV was written some time between 21 September and 2 December 1921, and first performed at the Manzoni Theatre in Milan on 24 February 1922. Pirandello explicitly called it a "tragedy." Towards the end of his life (he was to die in 1936), a ten-volume edition of his plays was produced under his control. Henry $I V$ appeared in volume three, published in 1933, together with two other plays which the author also referred to as "tragedies": Diana and the Tuda (Diana e la Tuda) and The Life I Gave Thee (La vita che ti diedi). This arrangement of Pirandello's plays in a thematic and stylistic (rather than chronological) order is maintained in the standard edition called Naked Masks (Maschere nude) published in 1948. In this edition, however, the word "tragedy" does not appear boldly under the title. It is retained only in a footnote concerning passages of the play that may be omitted

${ }^{1}$ George Steiner, The Death of Tragedy (London: Faber and Faber, 1961), 33. 
in a performance of "the tragedy." A new critical edition presents the plays in a revised chronological order: Henry $I V$ comes straight after Six Characters in Search of an Author, and unequivocally on its title page stands the restored rubric "tragedia in tre atti": "Henry $I V$, A Tragedy in Three Acts."2

Pirandello was no theoretician, despite his pretensions in that direction, but when he said "tragedy" he meant something definite by it. He was an intellectual from the provinces, living in Rome as a teacher of Italian literature and a literary journalist. Between the ages of thirteen and eighteen he "fulfilled his aim of obtaining a direct knowledge of Greek, Latin, and Italian literature." ${ }^{3}$ After studies at Palermo and Rome Universities, he successfully presented a thesis for a doctorate in philology from the University of Bonn in Germany. He was born at Caos (= Chaos) in the province of Girgenti (which became "Agrigento" in 1927), in Sicily - the Magna Graecia of the ancients, and a fertile land for ancient drama. A photograph ${ }^{4}$ shows an elderly Pirandello quite literally standing on classical ground: posing in front of the Temple of Concord in the valley of the Greek temples which includes of course a Greek theatre. Pirandello was a man who had lived for thirty-three years in the nineteenth century, who turned out to be one of Europe's leading modernists in the twentieth century; but he was in many ways a modernist malgré soi, a mixture of violent iconoclast and timid conformist, inhabiting an area intermediate between chaos and concord. ${ }^{5}$

\footnotetext{
2 Luigi Pirandello, Maschere nude, a cura di Alessandro d'Amico, vol. 2 (Milano: Mondadori, 1993, 4th ed. I Meridiani, 2001), 779.

3 Gaspare Giudice, Pirandello: A Biography, trans. Alistair Hamilton (London: Oxford University Press, 1975), 15. Giudice is quoting the testimony of Pirandello's son Stefano. Hamilton's book is a slightly abridged version of the Italian biography detailed in n. 4.

4 Gaspare Giudice, Luigi Pirandello (Turin: Unione Tipografico-Editrice Torinese, 1963), following page 488 .

${ }^{5}$ Kaos was the name the Taviani brothers gave to their film based on four of Pirandello's short stories. The implications of the name "Chaos," nice for biographers, were amusing for Pirandello himself (see his Frammento d'autobiografia: "...Io dunque son figlio del Caos [...]"). The dialectic of chaos and concord is evident in the conclusion to Pirandello's Preface to the Sei personaggi, in which he insists that his representation of chaos in this play is clear, simple and orderly.
} 
As a self-respecting twentieth-century writer who had tried to learn from the Italian futurists the special pleasure of being booed, Pirandello was duty-bound to surround the term "tragedy" with a good hedge of irony. In writing Enrico $I V$, it is as if Pirandello is sarcastically working on the basis of the prime definition of tragedy as given in the Oxford Companion to the Theatre:

TRAGEDY, a term applied to plays dealing in an elevated, poetic style with the grandeur and misery of man in his loftier aspects, as the plaything of fate and yet superior to it. [...] In the narrow theatrical sense of the word tragedy demands a cast of princes and demi-gods, an unfamiliar background-exotic, romantic, or imaginary - and a sense of detachment whose effect is heightened by the use of verse or rhetorical prose. ${ }^{6}$

So, oh bourgeois audience, you want a "tragedy" do you? You want to enjoy the frisson of lofty emotions and purge yourselves of pity and fear, that is to say digest your last ample meal before your next one? Well then, here is Henry $I V$ an historical costume drama such as are despised by those crazy futurists, ${ }^{7}$ about an eleventhcentury emperor, and from the title you may expect fine and expensive sets! Magnificent costumes!... Except that the play turns out to be not about Henry IV, but about a middle-class man in a private madhouse, who thinks (but doesn't any longer, or does he?) that he is Henry IV. At the end-which one might hope would be tragically strewn with Shakespearean or romantic corpses- "Henry IV" wounds a rival who does not die but is carted off to hospital,

6 The Oxford Companion to the Theatre, ed. Phyllis Hartnoll, 3rd ed. (London: Oxford University Press, 1967).

7 Balilla Pratella, "Manifesto of Futurist Musicians," Futurist Manisfestos, ed. Umbro Apollonio, translations by Robert Bain, R.W. Flint, J.C. Higgitt, Caroline Tisdall (London: Thames and Hudson, 1973), 37: "TO COMBAT CATEGORICALLY ALL HISTORICAL RECONSTRUCTIONS AND TRADITIONAL STAGE SETS AND TO DECLARE THE STUPIDITY OF THE CONTEMPT FELT FOR CONTEMPORARY DRESS." (For the purposes of this essay, see also Marinetti's assault on traditional theatrical performance in his 1913 manifesto "The Variety Theatre": "Systematically prostitute all of classic art on the stage, performing for example all the Greek, French, and Italian tragedies, condensed and comically mixed up, in a single evening [...] Soap the floorboards to cause amusing tumbles at the most tragic moments" (ibid., 130). 
and "Henry IV" does not die either, except metaphorically by withdrawing definitively into madness. Enrico $I V$ therefore is a "tragedy" about a "king" who suffers a reverse and "dies."

Almost right at the beginning, Pirandello directs a carefully aimed boot through the conventions of costume drama. Four young men in period dress pour on to the stage, three of them confusing the fourth as to where this apparently appropriately furnished throne-room is: it is either at Goslar, or in the Castle of the Harz, or at Worms, or in Saxony, or in Lombardy or on the Rhine (so much, it would seem, for the neo-classical, not classical, unity of place), and then one of the valets who is already on stage asks for a match and lights a cigarette. This moment is taken straight out of a futurist "synthesis" (as the futurists called their playlets) which was one of the pieces that used to be performed in New Zealand in the 1970 s by the radical theatre group Red Mole. In Dissonance ${ }^{8}$ a gentleman in modern costume interrupts a medieval scene in which a page is pouring out his heart to a lady, and asks for a light; the medieval pair apologise that they haven't got one, the gentleman apologises for interrupting and the scene of courtly love resumes, before the playlet is snuffed out in a matter of minutes. The play Enrico $I V$ therefore begins with a subversive scene of alienation, but not in a Brechtian sense. We later see modern-day characters dressing up in medieval costume to meet "Henry IV," but we are never invited to see these characters as real-life actors, only as modern characters becoming actors. Pirandello always re-instates the fictions of naturalistic drama which he feigns to break. As Raymond Williams has said, Pirandello only multiplies mirrors, and operates a mystification of a demystification. ${ }^{9}$

Despite the heavy ironies surrounding the figure of the never named madman who thinks he is Henry IV, the word "tragedia" and even more the word "tragico" are very much part of Pirandello's vocabulary. Indeed, after only one page of text, the historical Henry IV is described in this play as "Il grande e tragico imperatore," the great, tragic emperor. At the beginning of his

\footnotetext{
8 An English translation of Dissonanza is to be found in Michael Kirby, Futurist Performance (New York: E.P. Dutton \& Co, 1971). The translations (by Victoria Nes Kirby) in this book are amusingly unreliable, which adds an extra futurist dimension to proceedings.

${ }^{9}$ Raymond Williams, Modern Tragedy (London: Chatto and Windus, 1966) and Drama from Ibsen to Brecht (London: Chatto and Windus, 1968).
} 
lecture, first given in 1922 (the year of Enrico $I V$ ), which was written up and expanded into the essay "Teatro nuovo e teatro vecchio," $"$ Pirandello referred unproblematically to a playwright setting out to write "una commedia, un dramma o magari una tragedia" (227) in which the "magari" (=perhaps, or even) seems to suggest either that this form is unusual or difficult, or that the word itself is one not to be used lightly.

"Comedy," "drama" (or "melodrama") and, perhaps, "tragedy" form a series, as can be seen for instance in the post-scripted Preface to Sei personaggi. Here the words "commedia" and "dramma" are used very frequently, but not interchangeably. The play is formally, and as it strikes the audience when they see six grotesque "characters" invade a stage rehearsal and cause mayhem, a "commedia" - despite the fact that at the end two children die, of which more later. For the characters, however, caught up in a dreadful family situation which they want to have acted out, theirs is no comedy ${ }^{11}$ but the most serious and anguished drama. At two key points in this text the terms "commedia," "dramma" and not "tragedia" but "tragico" are used in sequence. And it might be said that the drama of the characters does begin to take on a tragic quality through the intervention of a higher albeit ironic intelligence: the characters are, unbeknown to themselves, not in the play - a drama - about themselves that they would like to be in, but in this particular play-perhaps a tragedy? — written by one Pirandello, in which they are straying around looking for an author to write up their story. According to his Preface to the play, Pirandello had considered their own story squalid and melodramatic, and had refused to write it; the story of this refusal has in it something tragic.

Pirandello particularly favoured this "misto di tragico e comico" (mixture of tragic and comic), and the two terms thus linked recur

\footnotetext{
${ }^{10}$ This is to be found in the invaluable $6^{\text {th }}$ volume of the standard edition: Luigi Pirandello, Saggi, poesie, scritti varii, ed. Manlio Lo Vecchio-Musti (Milan: Mondadori, 1960), referred to in subsequent notes as SPSV.

${ }^{11}$ With her very first words, the Stepdaughter proposes that the characters should become the theatre company's next "commedia," using the term in its more general Italian sense of "play," but almost immediately the Father corrects this to "un dramma doloroso," and "dramma" is always his preferred term, although even he does use the generic "commedia"; the Stepdaughter also soon changes to the more precise term "dramma."
} 
throughout his writings. To this mixture he gave the name "umorismo," which has little to do with the common English meanings of "humour" (as Pirandello points out at the beginning) and which constitutes Pirandello's particular variation on the wellworn theme of romantic and Hegelian irony. Pirandello's only substantial theoretical piece was his long essay (based on a course of lessons given at the Rome Teachers' Training Institute) L'umorismo, ${ }^{2}$ with a first edition published in 1908, and a second extended edition in 1920 - on the eve that is of his most radical plays. Having worked through derivations and exemplifications in part one of the essay, Pirandello makes explicit his own views in part two, relishing a disagreement with the leading Italian aesthetician, Benedetto Croce, in the process. His example of the comic is sadistic, and socially repressive and normative: we see an old lady with dyed hair, make-up and a young person's clothes; she is ridiculous and we laugh at her. This is termed the awareness of the opposite-we note that the old lady is the opposite of what an old lady should be like. We are then invited to imagine the pitiful circumstances which might have induced the old lady to get herself up in this fashion, and we can no longer laugh at her but feel for her. This admixture of pity in a human situation which is superficially grotesque constitutes for Pirandello the "humorous."13

In reviewing examples of the "humorous" in literature, Pirandello asserts that, when in Ariosto's renaissance epic Orlando furioso the paladin Orlando goes mad, "Scoppia la tragedia" (= tragedy explodes), and that Orlando's comic appearance is outweighed by his tragic madness. "In Orlando's tragic nature there is a comic element; in Don Quixote's comic nature there is a tragic element." Moreover, not only can the tragic intervene to outweigh the comic and vice-versa, but the comic can be made uncomic by something else which is comic, and the tragic untragic

\footnotetext{
12 Luigi Pirandello, On Humor, intro., trans. and annotated Antonio Illiano and Daniel P. Testa (Chapel Hill, North Carolina: The University of North Carolina Press, 1960).

13 The audience's double movement, of drawing back with a sort of (shocked and amused) horror and then reaching out in pity, is uncannily similar to Phillip Mann's interpretation of Aristotle's fear and pity (see below, "Tragedy in the Theatre: Interview with Director Phillip Mann," 225-26).

${ }^{14}$ Pirandello, On Humor (n.12 above), 83.
} 
by something else that is tragic. ${ }^{15}$ Either adjective can qualify its opposing noun, in a typically Pirandellian oxymoron-ever since, for instance, in the 1893 article on "Arte e coscienza d'oggi" (Art and Consciousness Today):

This poor earth of ours! A tiny astral atom, a vulgar little top thrown from the sun and moving round it, through space, in immutable tracks. What has become of man? What has this microcosm, this king of the universe become? Alas poor king! Can you not see King Lear hopping before you, armed with a broom, in all his tragic comicality? What is he raving about ${ }^{16}$

In the article on irony (published in 1920, that is to say again in the crucial period of his most radical works), Pirandello states that Frederick Schlegel's term of "transcendental farce" is eminently applicable to "many of the most significant modern grotesques"and it should be remembered that "the grotesque theatre" was a term used to describe the plays of a group of Italian writers with whom Pirandello shared a number of situations, themes and symbols. $^{17}$

When the character Henry IV eventually appears on stage in the play named after him, he has an appearance as grotesque as mad

15 The statement in L'umorismo that "il comico è anche superato, non però dal tragico, ma attraverso il comico stesso" (comedy is also surpassed, not however by the tragic, but rather through the comic sense itself [ibid.]) meets the symmetrical phrase in the article on irony, Ironia (1920) that "...una tragedia quando si sia superato col riso il tragico attraverso il tragico stesso, scoprendo tutto il ridicolo del serio, e perciò anche il serio del ridicolo, può diventare una farsa" (a tragedy, whenever the tragic is overcome with laughter by means of tragedy itself, revealing all that is ridiculous about seriousness, can become a farce) (SPSV, 995).

${ }^{16}$ The original is to be found in $S P S V, 870$. The translation is that by Hamilton in Giudice (n. 3 above), 55.

17 Pirandello became friendly with one of this group, Rosso di San Secondo, twenty years younger than himself, but another Sicilian. The play which launched the grotesque school was La maschera e il volto by Luigi Chiarelli, written in 1913 and first performed in 1916. The title indicates a favourite theme of Pirandello's. Jennifer Stone's Pirandello's Naked Prompt: The Structure of Repetition in Modernism (Ravenna: Longo Editore, 1989) to which the present article is heavily indebted, contains in its third chapter "Cubo-Futurist Collage" a discussion of futurist features in Pirandello's works. 
Orlando, mad Lear, mad Quixote or the ridiculous old lady of L'umorismo. According to the stage direction, his hair is patchily dyed, and on the "tragic pallor" of his cheeks he has bright red make-up, "like a toy." So this then is our tragic hero: a lunatic clown.

"In tristitia hilaris, in hilaritate tristis"-gay in sadness, in gaiety sad. That was Giordano Bruno's phrase which Pirandello tried to make his own. In view of this scrambling of the modes of tragic and comic, and the intertwining of the words in Pirandello's discourse, one might wish to conclude that Pirandello's drama was indeed one of the prime examples of "tragicomedy" which a number of critics have stated is the dramatic genre par excellence of the twentieth century, ${ }^{18}$ and that Pirandello is one of those who would agree with the assertion made by Socrates at the end of Plato's Symposium that the genius of comedy is the same as that of tragedy. The present essay, however, intends to resist as long as possible that rather easy conclusion, and ask what lies behind the aloof, ironic smile or grimace of the plays.

It is clear that, just as the moral tension in Machiavelli's political theory derives from the fact that the terms "good" and "evil" retain their meaning, so "comic" and "tragic" appear to have definite significations in Pirandello. Henry's pallor is tragic, just as Mop in Come tu mi vuoi is twice termed "tragic," or in I giganti a woman is described as having hair as red as the blood of tragedy, while another character has, disconcertingly, "tragic eyebrows." At this level, the uses of the adjective point to there being a traditional appearance, manner and acting style seen as appropriate to tragedy, which Pirandello fully accepts, however selectively he wishes to employ it. At the level of plot, a situation may be defined as tragic if, however ridiculous and absurd it may be, it is ineluctably frozen in suffering. Pirandello's first surviving play, of which the first version dates back to 1892, and to which he remained extraordinarily attached, had its original title of L'epilogo (The Epilogue) changed to La morsa (translated as The Vice). Pirandello's plots show the process of an already existing situation closing over his characters as in a vice, while the author feigns his

18 See for instance Karl S. Guthke, Modern Tragicomedy (New York: Random House, 1966), and David L. Hurst, Tragicomedy (London and New York: Methuen, 1984). 
absence. Irony or humour is that space between the writer and his creation in which he files his nails.

In referring to his own life and the lives and deaths of others, Pirandello made free use of the word "tragic" in what might be thought its debased and untechnical sense ("he died so suddenly and so tragically"); except that he uses the word with a particular emphasis. He wrote of his own family situation in various of his short stories. In Suo marito (Her Husband) he wrote of a man, himself, victim of the pathological jealousy of a wife who was going mad:

He felt his bowels tighten and his heart turn sick at the constant mockery and fierce denigration. For he felt the atrocious absurdity of his tragedy: to be the target of madness, to suffer martyrdom for imaginary faults. [...] Everything inspired such a sense of disgust in him, such a dreadful sense of humiliation, such a bitter and black sadness that he withdrew at once from contact with others and, on his own again, empty and horribly lonely, he would contemplate his misery, tragic, ridiculous, and irremediable. ${ }^{20}$

Antonietta Pirandello née Portulano was finally tricked into going to a psychiatric clinic at the end of 1918, but it was not until 1924 that all hope of her coming out of the clinic was given up. ${ }^{21}$

The vice in which Pirandello and his characters were caught was the bourgeois family, that machine for producing neurosis. Meanwhile, the social and political "background," hardly ever referred to explicitly in the plays, was turbulent in the extreme. Between the family anxieties that occurred during the First World War - the captivity of Pirandello's eldest son Stefano, and the

\footnotetext{
19 Stephen Dedalus in Joyce's A Portrait of the Artist as a Young Man (London: David Campbell Publishers, 1991), 269, is speaking of the artist reaching the "dramatic form" having emerged from the lyrical and epical: "The artist, like the God of creation, remains within or behind or beyond or above his handiwork, invisible, refined out of existence, indifferent, paring his fingernails." A Portrait was published in 1916, Pirandellian years, and this is also the indifferent God who presided over the First World War. A page earlier, Stephen has posed the question, "Is a chair finely made tragic or comic?"

${ }^{20}$ The translation is Hamilton's in Giudice (n. 3 above), 84.

21 Camille Claudel, Antonietta Portulano, Vivien Haigh-Wood-three real-life examples of that madwoman in the attic prophesied by Charlotte Brontë.
} 
death of his mother - and the final renunciation of Antonietta, there occurred the failed workers' revolution in the north, and the rise of fascism. In total accordance with the interests and chauvinistic instincts of his social class and regional origins, but impelled too by that iconoclastic violence which Pirandello himself betrayed and to which he was attracted, Pirandello joined the Fascist party in the most ostentatious way and at the most provocative juncture possible through a public letter sent to "one of the most fanatic fascist papers, L'Impero," 22 which was printed on 19 September 1924 , in the wake of the fascist assassination of the socialist deputy Giacomo Matteotti. Already a year earlier a fascist newspaper had printed "an enthusiastic homage by Pirandello to Mussolini," 23 on 28 October 1923, the anniversary of the so called fascist march on Rome. In it Pirandello had justified Mussolini's actions in terms of a dialectic of "form" opposed to "life," a rationalisation of his own thought which the critic Adriano Tilgher had offered him, and which henceforth became a straightjacket for Pirandello's own thinking:

Mussolini can receive only blessings from somebody who has always felt the immanent tragedy of life which ... requires a form, but senses death in every form it assumes. [...] Mussolini has shown that he is aware of this double and tragic law of movement and form, and hopes to conciliate the two. ${ }^{24}$

The critic Raymond Williams, referred to above, sought to explain plays in terms of a "structure of feeling," which provides a mediation between individual authors and the particular societies in which they live. Pirandello, in conformity with an idealist aesthetic, adamantly positioned his plays in the sphere of Art, out of the reach of materialist contamination. The obsessively repetitive structure of feeling in his plays, however, is to be found in a neurosis which is produced socially, and displaced through a series of resistances which produce the hall of mirrors that is umorismo.

\footnotetext{
${ }^{22}$ The quoted phrases are in Giudice (n. 3 above), which has a full chapter entitled "Fascism."

${ }^{23}$ Giudice (n. 3 above), 145.

${ }^{24}$ Pirandello in L'Idea Nationale, 28 October 1923 in Giudice, ibid.
} 


\section{Incest}

Cultural life in "western civilisation" in the twentieth century has been lived in the shadow of three thinkers born (like Pirandello) deep in the nineteenth century: whether we like it or not, and many-including Pirandello-have not, we have all been darwinians, marxists and freudians. In fin-de-siècle Vienna Freud, startled at the number of cases of neurosis which seemed traceable to childhood incest, produced the notion that the neurosis was not a trauma resulting from actual incest, but rather the result of a desire which had been suppressed in the unconscious. Freud introduced the concept of an "Oedipus complex" in his Die Traumdeutung of 1899; and it was in this revised form that the great myth of that play which is at the centre of Aristotle's Poetics entered the twentieth century and took centre stage again, with Oedipus as Everyman.

As you would expect, "Pirandello always denied any knowledge of Freud or of psychoanalysis, just as he refused to acknowledge any other influence on his work." 25 In Come tu mi $v u o i$, a play written in 1930 in which a man and his extended family are called on to make a choice between two alternative wives, one mad and unrecognisable, the other a surrogate identical with the original, the madwoman who is brought from Vienna is almost totally catatonic: the "talking cure" certainly hasn't worked for her. Nor does it work for Pirandello's other characters, even though they suffer from chronic logorrhoea.

Pirandello himself had become subject to a fantasy of incest: his daughter Lia, whom her father always addressed with the affective diminutive as Lietta, confirmed that her mother accused her husband and daughter of committing incest. Lietta, appalled, tried to commit suicide. This was the loving Lietta whom Pirandello later partially cut out of his will in favour of "the daughter of his choosing," the Milanese actress Marta Abba, with whom Pirandello had fallen in love, who had acted in and inspired so many of his plays, and who, through Pirandello's 1926 will which remained valid, inherited the copyright of nine of Pirandello's last fifteen plays.

${ }^{25}$ Giudice (n. 3 above), 217. 
Incest had been a favourite romantic and post-romantic themeSteiner refers to Shelley, Byron, Wagner, Alfieri. ${ }^{26}$ It continues into the twentieth century with various writers, but without doubt the greatest writer to restage Oedipus is Pirandello. The theme emerges both explicitly and in various disguises. In Così è (se vi pare), a fascinating play of 1917 which has been treated as a manifesto of Pirandellian "philosophical" ideas about the lack of objective truth and of fixed identity, and which seemed to open the floodgates of dramatic composition for Pirandello, he pushed the short story which is its source towards a heightened provocation. In this "parable in three acts," the respectable (if comically ridiculous) townsfolk are obsessed to know the truth about the triangular relationship between Signor Ponza, his wife, and his mother-in-law Signora Frola. Signora Frola maintains that Ponza's wife is really her daughter, returned from a sanitarium where she had gone to recuperate from the violence of Ponza's love. Ponza on the other hand maintains that his wife, Signora Frola's daughter, has died and that the present wife-who lives locked away from everyone including Signora Frola - is his second wife, a completely different woman, who however has agreed to pretend to be Signora Frola's daughter, to humour her in her madness. Curiously, Signor Ponza and Signora Frola spend a great deal of time together. In a series of coups de scène, Pirandello makes the townsfolk and with them the audience swing between these mutually exclusive alternatives. At the very end of the play, the mysterious Signora Ponza appears, her face covered by a thick black veil. Instead of being a beaten, submissive young wife, she imperiously tells her husband and her mother(?) to depart, and amazingly they depart the scene arm in arm, caressing each other, weeping together, and whispering affectionate words. Thereupon, rather than reveal her true identity, Signora Ponza solemnly announces that she is whoever people think she is. Moral of the parable: Truth is impenetrable, there is no such thing as non-subjective Truth.

The first reaction of an obstinately positivist audience to this play is that Pirandello has simply cheated-first by having all marriage and death certificates destroyed in a natural disaster, then by totally suppressing Signora Ponza as a character and reducing her to an allegorical cypher. As will become normal, Pirandello has

${ }^{26}$ Steiner (n. 1 above), 214. 
deflected attention from the extreme violence and ferocious repression of the nuclear family towards a specious philosophical problem. But what is adumbrated in this play is an Oedipal triangle, with Ponza in an obscure sexual relationship with his mother(-in-law), and an immured Antigone-like wife-daughter (-sister?). The blurring and doubling of the figure of the younger woman is typical in Pirandello: for instance, in Sei personaggi the Stepdaughter is doubled by the actress; in Enrico IV, Matilda is doubled by her daughter; in Diana e la Tuda, Tuda is doubled by her statue; in Come tu mi vuoi, Lucia is doubled by the Ignota.

In the post-scripted Preface to Sei personaggi in cerca d'autore, in which Pirandello fully appropriates authorship of a play which he pretended to write himself out of, he claims not to have wanted to write up the melodrama of the petit-bourgeois family because it lacked any philosophical dimension; instead he wrote the tragicomic mixture of their search for another author. The melodrama is potentially tragic, but Pirandello evades that through swathes of irony. The result is that, in the Mondadori edition approved by Pirandello, the play is placed together with Ciascuno a suo modo and Questa sera si recita a soggetto in a category of plays about theatre, and critical attention is focussed, logically enough, on the play that Pirandello did write, not the play that he resisted writing. That other play involved prostitution, incest, and a double child suicide.

The uproar caused by the first performance is assumed to have been on aesthetic grounds: the audience was affronted at being faced with a totally bare set with stage hands hammering, and then at the invasion of the stage via the auditorium by six oddities and at the higgledy-piggledy action that ensued. In puritanical England, however, that was irrelevant; the Lord Chamberlain refused to license the play for public performance on moral grounds. ${ }^{27}$ The first act of the "play to be made" about these six characters is set in a brothel where, after a first scene between the madame and a young prostitute, the latter is only prevented from having sex with her stepfather by the sudden irruption of her mother.

Apart from the problem of getting the story past the censors, a playwright who wanted to take on the task of dramatising the

${ }^{27}$ In England the play was first performed privately on 26 February 1922, by the Stage Society of London at the Kingsway Theatre. 
characters' story would have his or her work cut out. The inept Stage Manager of Pirandello's play, who turns out not to be the author that the characters are looking for, decides to plunge in medias res, and place his first act in the brothel. The next act he tries out is set in the garden. It is never clear where a third act is going to fit in.

The Stage Manager is probably right in setting the first scene in the brothel, where between them Madama Pace, the Stepdaughter-who would need a name (she is typically unnamed in Pirandello) - and perhaps another prostitute could get a good deal of the complicated exposition out of the way. One problem that does arise, and brings the action to a stop in the Capocomico's [i.e. producer/director's] version in Sei personaggi is that this scene would really require far more naked female flesh than either Rome or London would allow. The only alternative to beginning with the brothel would have been either to stage as the first act the break-up of the Father and Mother that occurred so many years earlier, and this surely would have been extremely tedious; or else a domestic scene in the widowed Mother's household, showing the Stepdaughter's decision to become a prostitute-a desperately naturalistic piece of domestic drama, wholly un-Pirandellian. Anyway, Pirandello's plays always begin (like King Oedipus) after the fatal causes of the subsequent events have already taken place, so let us place act 1 in the brothel. After act 1, things get more difficult, however.

It is not clear whether, in the hypothetical play that Pirandello didn't write and that we are here trying to construct, the second act should indeed be in the garden (as the Capocomico decides), culminating in the death of the two children, with the third act being that merely adumbrated in the tableau at the end of Pirandello's play: the Father, Mother, Son and Stepdaughter plunged even more deeply into a hell of non-communication until the Stepdaughter breaks free; or whether all that should constitute the third act, and the second be a mournful and static act of the family reunited again after the incident in the brothel-but once again this would be boringly undramatic. Certainly, except for the melodramatic deaths, the action peters out and becomes frozen, leaving no culminating gesture for the father. In any case, our hypothetical writer has to solve the question of whether to play the second act in the garden and the third act in the house, or vice versa, sorting out the futurist simultaneity which the Father 
demands into the sequential divisions of a well-made three-act play with three separate stage sets. For his second act the Capocomico runs into the double technical problem of a character (the son) refusing to participate in a scene, and a double action which to make sense needs to be played simultaneously: the little girl would not have drowned in the fountain, if the mother had not been trying (unsuccessfully) to speak with her son. ${ }^{28}$

The problem with writing up the characters' story is thus partly technical, but also and crucially psychological: Pirandello's only way of writing up a story hinging on incest interruptus is in fact to do so in the way that he does: to write the story of how difficult, indeed impossible, it was to write it, let alone stage it, fully. Although the audience's and critics' attention tends to shift to the metatheatrical level on the one hand, and to discussions of meaning and identity on the other, the heart of the play, to be written and as in fact written, remains the incestuous family. Only those who have worked on the play or have seen it will know-what can with difficulty be gained from a reading: the extreme pathos of the two children who remain mute through the whole play, sacrificial victims in a welter of words. ${ }^{29}$

The story of the six characters falls short of completion, and quite deliberately the melodrama is skewed in the direction of

28 The futurists had made some interesting experiments in simultaneity, which was a key principle of their theory. Both the futurists and Pirandello himself were also deeply interested in the new techniques of narration provided by cinema. At the very end of his life Pirandello proposed a script for a film of Sei personaggi, on which he would collaborate with Max Reinhardt - the producer satirised in Questa sera si recita a soggetto as "Doctor Hinkfuss." Pirandello reinstated himself at the centre of the action: the film was to show the author refusing and being haunted by the characters, and that author was to be played by Luigi Pirandello.

${ }^{29}$ The Italian Department at Victoria University of Wellington has performed two productions of Sei personaggi, in 1981 and 1995, testing both the ways of playing the characters that were used in the earliest performances-with masks and with heavy stylised make-up. Both productions were bilingual: in the earlier production, the Capocomico functioned as translator to the English-speaking actors (and audience); in the later production, the actors too spoke Italian, and the Capocomico communicated directly in English only with the show's stagemanager and crew, and to the audience. Although played in a proscenium arch theatre, Pirandello's massively thick invisible wall was thus broken. This production was advertised as a performance of Enrico $\mathrm{IV}$. 
comedy. But what Pirandello dropped from his postscripted rationalisation of the play was its very first sentence, as it appeared in an earlier French version published in July 1925 in the Revue de Paris: 'J'ai écrit les Six personnages en quête d'auteur pour me délivrer d'un cauchemar." ${ }^{\prime 30}$ (I wrote Six Characters in Search of an Author to free myself from a nightmare.) The nightmare of those particular characters is echoed in the next play, Enrico $I V$. Enrico, desperately in love with Matilde, falls from his horse in an historical cavalcade when he is in his late twenties. Time stops for him there. He recovers 12 years later to find he is dressed up as a German emperor, and in a spirit of bitter umorismo chooses to continue in his role, now fully conscious that he is acting a part. After eight years of consciously acting out his role, and shortly after the death of his sister-mother whom he has not seen for all these twenty years (sister in real life, who has cared for him through these twenty years, and whom Henry IV has cast as his mother in the tragical history he is acting out), Matilde comes to see him. She has had a daughter, Frida, by another man who is now dead. Another of the party who accompanies Matilde is her cynical companion and presumed lover Belcredi, a second figure who has usurped Enrico's position with Matilde. Frida is heavily eroticised. She is identical in appearance to Matilde at the time of the accident: for Enrico it is Frida, not Matilde, who is the true Matilde. In addition she is the daughter that Enrico would have had, might have had-perhaps did have, although that thought is deliberately erased in the play. Were Enrico now to marry Matilde and live happily ever after-which is, incredibly, what happened in the Hollywood film version ${ }^{31}$ of the play (equivalent to Ophelia being fished out downstream and ending hitched to Hamlet after all) - Frida would be his stepdaughter. In a moment of fury at having missed out on everything that life had to offer, Enrico seizes Frida as rightfully his, in a violent and hopeless gesture which provokes the catastrophe. The pattern of the two plays Six Characters in Search of an Author and Henry $I V$ is thus similar; in the following diagram the symbols $=$ and $(=)$ indicate sexual

\footnotetext{
${ }^{30}$ Quoted in Stone (n. 17 above), 89.

31 Henry $I V$, directed by Marco Bellocchio; screenplay (Italian with English subtitles) by Marco Bellocchio, with the collaboration of Tonino Guerra, freely adapted from the play by Luigi Pirandello (a Rai Radiotelevisione Italiana Rete QTV-Odyssia production).
} 
relations consummated or near consummation. The plays point an arrow of desire straight from the Father/Enrico to the Stepdaughter/Frida.

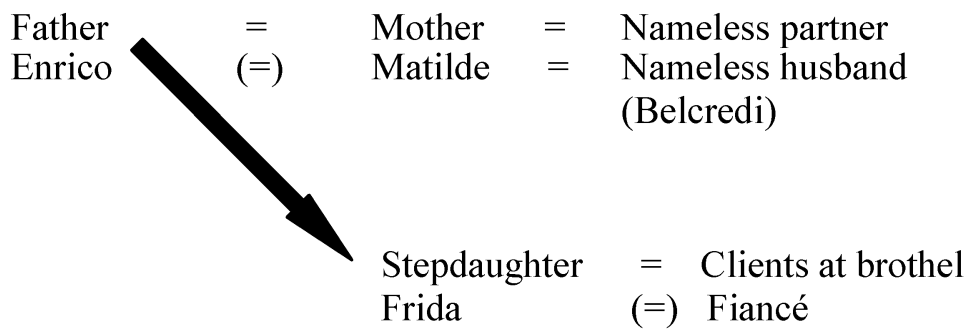

Frida's fiancé is Enrico's nephew who is now replacing Enrico in Frida's (that is the young Matilde's) affections. The nameless partner who took the place of the Father was a younger subordinate in his office. The Father and Enrico, in a perverse gesture of castration, consciously or unconsciously abandon their partners. It is as if, in these plays, the close relationships of the nuclear family are all slightly shifted, skewed, blurred, and that this is the nearest we can get to the authentic and obsessively repeated nightmare. ${ }^{32}$ Pirandello seeks to set himself at a remove, watching this Oedipal drama as if from the position of a dead Laius.

When Pirandello was a boy, he loved the puppet theatre for which Sicily is renowned. In a short story La scelta (The Choice) he recounts how he used to keep going back to the store selling marionettes at the toy fair, accompanied by his mean-spirited tutor:

"Take Orlando, sir!" the shop-keeper advised me. "The champion of France: I'll sell him to you for ten and a half lire...."

But Pinzone, who had been cautioned by my mother, burst out:

"Ten and a half lire? It's not worth three farthings. Look at him: he's got a squint! Besides, he may have been Champion of France, but he was also a raving lunatic!"33

32 For a detailed psychoanalytic analysis of Pirandello's texts, explicitly examining the structure of repetition, see Stone (n. 17 above), 79-176.

33 Quoted in Giudice (n. 3 above), 12. 
Finally, in Enrico IV Pirandello has his noble hero, marionette, and raving lunatic. But is the story of the passion of a much older man for a much younger woman, with all the banal implications of incest, really the stuff of tragedy? Would it rate more than a couple of inches on the crime page of the local rag? ${ }^{34}$

\section{Violence}

"Tragedies end badly." "The Hero of tragedy must suffer; to this day that remains the essence of tragedy." In tragedies people almost always die, everyone knows that. Generally it is the hero, who manages to take a fair few along with him for the ride. A tragedy does not have to have a villain like melodrama, but can be sheeted home to a sin or flaw ("The fault, dear Brutus, lies not in the stars, / But in ourselves..."); a Hollywood world divided simplistically into goodies and baddies is as inimical to tragedy as is marriage signifying a happy-ever-after. That is not to say that there are not villains a-plenty in tragedies, but we must add that the hero himself may also be consciously or unconsciously the archvillain, provided there be some "greatness of spirit (or language)" to compensate. The great saint is to the great sinner closely allied, and extremes may meet in the sacrificial victim of tragedy.

I am not competent to judge the anthropological merits and demerits of René Girard's book Violence and the Sacred (and one is naturally suspicious of a book which presents a general theory to account for not only all mythologies and rituals but the whole of human culture, especially one which only reaches 318 pages of text by virtue of being repetitive). ${ }^{35}$ The book is refreshing, however, in its rejection of the myths at the basis of liberal humanism and of the great optimistic dream of progress. Girard places violence at the very core of human society as the basis of religion and culture.

\footnotetext{
34 The present chapter was first drafted in 1998 and revised in 2001. Appalling cases of child abuse have emerged in New Zealand as in other countries in recent times, and the scale of the problem is less a matter of taboo than it once was. 2000 was a terrible year for child deaths in New Zealand, a country which is afflicted also by fearful statistics of youth suicide. This chapter in which attention is paid to a play dealing with the family in crisis culminating in the deaths of two children has been influenced by this context. [The situation is no better in 2010_Eds]

35 René Girard, Violence and the Sacred, trans. Patrick Gregory (Baltimore and London: The Johns Hopkins University Press, 1977).
} 
I call this "refreshing" because having emerged from a century of genocide and torture carried out on an unparalleled scale, ${ }^{36}$ it seems all the more idealistic to hope that tragedy can be made redundant by universal education, a free health and welfare system, a benign police force, and a cure for cancer. "We persist in disregarding the power of violence in human societies."

"Can there be literature after Auschwitz?" was a question posed by a number of writers and critics of that generation. In his belletrist approach to tragedy, George Steiner, armed with neither anthropology nor literary theory, circles obsessively around the problem in The Death of Tragedy, a book shot through with contradictions, and constantly belying its title. The assertion that the ideology of Christianity is inimical to tragedy cries out for a serious analysis of Calderón-if Shakespeare or Racine will not already suffice-, while in recounting a journey through Poland, it seems not to have occurred to Steiner to interrogate Polish theatre, perhaps the most vital in all of Europe in the decades immediately following the Second World War.

Girard's general thesis is that, in order to prevent "reciprocal violence" that will totally destroy a society, a "sacrificial victim" is created upon whom a communal act of "regenerative violence" is committed. The sacrificial victim is simultaneously object of loathing and reverence. He, she or it represents the sacred, which is, through the death of the sacrificial victim, banished from the community. Violence and the sacred are synonymous terms; they dwell outside the community, they are "the gods" created by the community, and only by propitiation can they be kept at their distance. Woe to the society that is visited by the violence of the sacred. If all "gods" are created by humankind, and all societies do this, so that-in Girard's view-society cannot exist without

\footnotetext{
${ }^{36}$ To the poor individual soul who suffers, there is no difference between the unspeakable horrors of the Elizabethan star chamber and a Gestapo prison, and there may be something Eurocentric and historically blinkered in seeing the mass murders of the twentieth century as too much out of the ordinary. Nevertheless, the Nazis' application of such a refined bureaucracy and technology to the extermination of children, women and men remains at the centre of western "civilisation" in the twentieth century, a deliberate violence unprecedented in scale. In New Zealand at the time of writing there was some heated debate over the use of the words Holocaust and Genocide.
}

${ }^{37}$ Girard (n. 35 above), 262. 
religion, it no longer makes sense to ask whether "tragedy" can exist without a metaphysical superstructure, for each writer and each work create of necessity their own metaphysic. The key question for tragedy, therefore, after the collapse of neo-classicism and romanticism, is still: how is the violence and aggression channelled: who dies, can that person in any meaningful way be seen as a "sacrificial victim," and what is their relationship with the generality of citizens once figured in the chorus. To encounter tragedy is to experience vicariously our own violence and our own deaths.

In bourgeois tragedy, as the sacred figure of the king lost its totemic power, the artist (whose great wits are "sure to madness near allied") and, in an increase of pathos, women and children assume the position of the "sacrificial victim," and the culmination of the community's hostility to the tragic victim is even more frequently that of enforced suicide - a classic solution, with the gun or death by drowning replacing the stage knife held against the heart. This is the fate of the two children whom the wordy Father and the self-important Stage Manager displace from the centre of Six Characters in Search of an Author, the mute children whose tragedy is and isn't being written, whose anger and tears we have to imagine: the miserable, sulky, neglected teenager and the fouryear-old little girl dressed in white with a black sash.

It remains highly dubious to what extent a society can be cathartically cleansed by such propitiation rather than by social reform: the death of Hedvig, daughter or stepdaughter of Hjalmar Ekdal, the "wild duck" of Ibsen's play, is not going to make a

\footnotetext{
38 Modern dance is an art form which, perhaps more than what Italians call "prose theatre," is given to exploring human violence. The remarkable New Zealand dancer and choreographer Douglas Wright has been explicit in saying that violence is one of the sources of his work: "Sometimes I watch what we make, and it is violent, and there's something in me that thrills to that violence, is very moved by it. It's cathartic really, actualising something that is hidden until it happens, all the tacit realities that are not spoken, that happen in the dark. But the violence I use has a purpose, it provides the opportunity to take us beyond that violence to an understanding which is more powerful in its effects than the violence is" (Raewyn Whyte, "Buried Venus: An Interview with Douglas Wright," Landfall 191 [1996]: 45). See also Douglas Wright, ghost dance (Auckland: Penguin Books [NZ], 2004), 247: "For me dance has been cathartic; I went for the jugular, mining wounds for hidden treasure." (Quotations and references provided by the editors)
} 
halfpennyworth of difference to the society within the play, although it may properly shock the audience which is reflected in the mirror held up to it. In Six Characters, the "tragedy" which has tended to concentrate, in the dialogue, on the figure of the incestuous father shifts onto the innocent children, but the double suicide is undermotivated, and it is not clear where it properly belongs in the "play to be made," the drama to be written up by some other author. In another gesture which is only sketched, the Stepdaughter turns seagull and flies free of the family prison with a sardonic cackle - can this be comedy after all? She leaves the Father, Mother, and Son, frozen mutely on stage, endlessly repeating their traumas, again and again and again, with no hope of any release for all eternity. There is no possible act of liberatory violence that is going to free them. Faced with so much only partially understood complexity in which he is intimately embroiled, Pirandello cannot achieve, does not want to achieve, in fact does everything he can to resist, the appalling seriousness and ultimate simplicity of tragedy.

Jennifer Stone rightly calls Six Characters in Search of an Author Pirandello's "manifesto of the family," and subsequent plays continue the scrutiny of the family neurosis. It is in Henry $I V$, alone of all Pirandello's plays, that the father is situated squarely at the centre of the play-in Six Characters the Father has to fight for the centre-but Henry IV is a "father" of a peculiar sort, orphaned of his sister-mother, his mother-wife, and his wife-daughter, reconsigning himself to a spiritual death allowing the "community" - the mundane characters on stage, and the audience in the auditorium - to turn its back on him and return to everyday life. The action happens in a castle which can be anywhere in the Holy Roman Empire, but which possesses the unity of a villa in Umbria. In fact, it is a painted stage, which actually represents a space of the mind. Pirandello has broken not all, but most of the bonds of naturalism, and the most radical and successful modern presentations of Pirandello's plays tend to be those which opt for a surreal, symbolic, expressionist manner of staging to recapture the original Pirandellian sense of "nightmare."39

39 See Massimo Castri, Pirandello Ottanta, ed. Ettore Capriolo (Milan: Ubulibri, 1981), for sets used in his Pirandello productions, especially that for La vita che ti diedi. 
The twentieth century's staging of King Oedipus, with all its social and political repercussions, is situated in the individual conscious and unconscious mind, and Pirandello's theatre at the time of Six Characters in Search of an Author and Henry IV presents a sequence of extremely bad dreams. The characters run and get nowhere: they strive to deny the social roles in which they are trapped, the inauthentic selves defined in the gridlock of family relations; a number of them aspire to die and to assume a false identity, to be no-one, nameless, and thus free. That inevitably runs up against the taboos which are the basis of society, first and foremost the incest prohibition.

The iconoclastic violence which Pirandello affected in the cultural sphere, and which drew him in a crucial creative moment of his life to fascism, ultimately turns against itself in self-loathing. Pirandello remained profoundly conservative and therefore, for all his protestations to the contrary, totally pessimistic. There is nothing of the social battler in Pirandello, as distinct from the giant of the north, Ibsen, to whom he felt a profound aversion because he represented a real threat to Pirandello's precarious equanimity, his self-imposed detachment:

What does this Norwegian want? Nobody can really understand him, but it is enough for someone to seem incomprehensible for him to be surrounded by a swarm of undecided individuals as insistent, as oppressive as, if I may use so vulgar an expression, flies surrounding a spittle. $^{40}$

In a curious justification of fascism found in a printed conversation with Telesio Interlandi, Pirandello saw certain social institutions as "colossal pillars," "dead things," "static blocks" which were nevertheless "elementary necessities": these were "the Monarchy, the Unitary State," "the Family," "the Church."41 Of these, we have seen that the Family is the scene of those traumas which Pirandello's characters obsessively repeat without hope for

\footnotetext{
${ }^{40}$ Giudice (n. 3 above), 104 (words written by Pirandello in 1893).

41 Ibid., 152.
} 
themselves of catharsis, a prison, or, to quote the title of an influential book of Pirandellian criticism, a torture chamber. ${ }^{42}$

The language in which the action is couched possesses an extraordinary energy, clarity and flexibility: the dialogue should be spoken like walking on broken glass. Nevertheless it also retains the formality of being literary (in a country where the majority of the population spoke dialect; and indeed Pirandello's first forays into the world of theatre used Sicilian dialect ${ }^{43}$ ). Pirandello became a rootless cosmopolitan, but retained a strong Sicilian accent. The characters in his tragedies speak proper Italian, however (and indeed Pirandello became a teacher of stylistics), and declaim in that grander manner which is still far more permissible on the Italian stage than on one where English is spoken. The dramas are played out as spoken action, speech as action, punctuated only by rare moments of physical violence. Nevertheless, the potentiality for violence underlies the speech, and physical violence does break out in both of the plays discussed here. ${ }^{44}$ The symbolic action of the dreamwork is thus conducted in a language of the intellect disrupted by violent passion. Pirandello retained a perhaps Mediterranean and classical sense of panic and Dionysian madness underlying civilised society, of the abyss into which we fall. Concord and chaos.

Pirandello died, of course, before he could see what havoc was wrought on Italy by Mussolini who, according to Pirandello, "always felt the immanent tragedy of life." The stage-directions for Pirandello's own final act had been written, histrionically, twenty-five years earlier:

1. My death must be passed over in silence. [...] No announcements or invitations to the funeral.

2. Do not dress my corpse. Let me be wrapped naked in a winding sheet. And no flowers on the bed or lighted candles.

\footnotetext{
42 Giovanni Macchia, Pirandello o la stanza della tortura (Milano: Mondadori, 1981).

43 Pirandello, Maschere nude, vol. 4 (Milano: Mondadori, 2007). (Editors' reference)

44 The critic Adriano Tilgher rightly noted, with regard to one of Pirandello's plays, that it was full of "a bitter, open, lucidly logical violence."

${ }^{45}$ Giudice (n. 3 above), 145.
} 
3. A pauper's hearse. Bare. No one to accompany me, neither friends nor relations. [...]

4. Burn me. And as soon as my body has been burnt the ashes must be thrown to the winds, for I want nothing, not even my ashes, to remain. $[\ldots]^{46}$

So much for catholic and fascist pomp and circumstance (and indeed these instructions from a Nobel prize-winner were taken as a slap in the face for the regime). However, resigning himself to the ineluctable return to his origins, and offering to the actors an alternative ending to these last obsessively detailed stagedirections, he added:

But if this cannot be done the funeral urn must be taken to Sicily and walled into some rough stone near Agrigento, where I was born.

At Agrigento, but in the Museo Comunale "unnoticed amongst all the archeological material" they remained, in Pirandello's favourite Greek vase. Thence they were returned to "Chaos" and were buried under a tree next to the house where he was born. Thus this writer returned from theatrical first nights in capitals around the world to the ancient land colonised by the Greeks which he had abandoned and which, like a vice, clicked shut on him.

${ }^{46}$ Ibid., 207. 